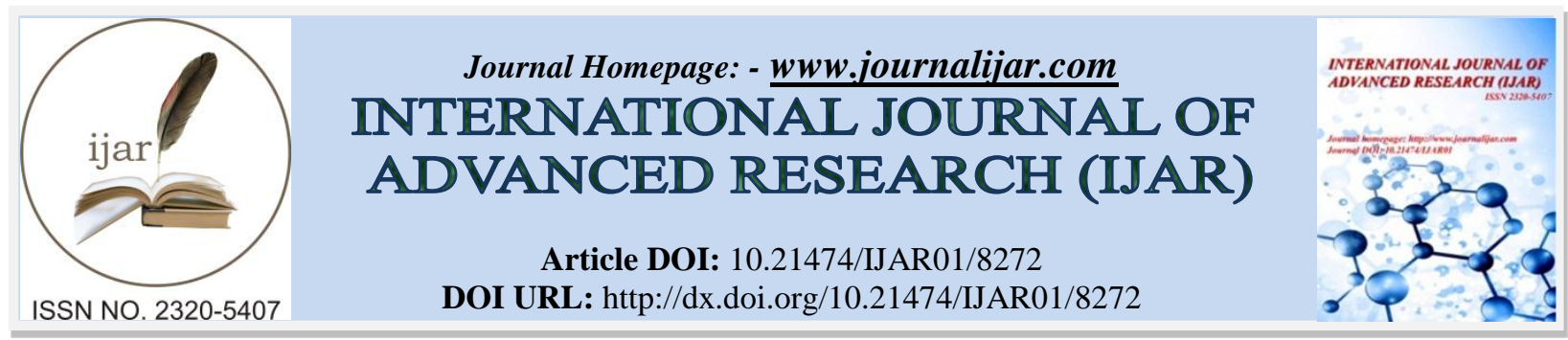

RESEARCH ARTICLE

\title{
POLYMORPHISM OF COI GENE AND ITS ASSOCIATION WITH MILK PRODUCTION AND LAMB'S GROWTH BEFORE WEANING OF IRAQI AWASSI SHEEP.
}

\author{
Asaad Y. Ayied and Bashar F. Zaqeer. \\ Animal Production Department, College of agriculture, University of Basrah, Basrah, Iraq.
}

\section{Manuscript Info}

\section{Manuscript History}

Received: 20 October 2018

Final Accepted: 22 November 2018

Published: December 2018

Keywords:

COI, mitochondria, Awassi sheep, genetic polymorphism.

\section{Abstract}

This study was conducted in the Laboratory of Genetic Engineering/ College of Agriculture/ University of Basra. It aimed at measuring the genetic polymorphism of COI within the mitochondria of Awassi sheep and its relation to milk production and therefore the growth of lambs till weaning. Data were collected from eighty-seven ewes with their lambs (87 lambs). Milk and blood samples were collected from ewes. Body weight of lambs at birth and each 15 days until weaning also included. Milk samples were collected every 2 weeks till the age of weaning. DNA was extracted from the blood and the polymerase Chain Reaction (PCR) technique was used to amplify the COI gene. After that the amplification product was purified and samples were analyzed by the Korean Macrogene Company for DNA sequencing analysis. The Alignment sequences were aligned with the standard sequences published within the National Biosciences information Centre (NCBI) using the BioEdit program. The genetic polymorphism, haplotype and nucleotide diversity were estimated using Dnasp v5.10 program. The genetic distance, molecular variation AMOVA and neutral test by Arlequin ver. 3.5.1.2. The haplotype network was determined by the net 5.0.0.0 program. The tree of evolution was developed using MEGA 7.0. COI gene showed the presence of a thirteen genetic polymorphism in the breed of Awassi sheep. The diversity of the haplotype (HD) and therefore the nucleotides $(\pi)$ of this gene was high $(0.852,0.00391$ respectively). The total number of haplotypes $(\mathrm{H})$ was nine. The number of haplogroup of COI factor was 3 . While the genetics and evolution tree of COI showed that there were 3 main branches when compared with sheep breeds of different countries. Awassi sheep breed appeared in a separate branch from the other breeds of these countries. The results of the AMOVA showed that the variation within the breeds is a lot of bigger than the variation between breeds $(13.52 \%$ vs $86.48 \%$ ). The results of the neutrality test exhibited negative values, which indicate AN enlargement of the Iraqi Awassi sheep breed. The overall average milk production, birth weight and weaning weight $(522.99 \mathrm{~g}, 4.52 \mathrm{~kg}$ and $17.73 \mathrm{~kg}$ respectively) were non-significantly associated with COI. However, COI polymorphism associated significantly weaning weight. Therefore, COI can be used as a genetic marker to genetically improve weaning weight in this breed since it showed high genetic variation among individuals (within the breed).

Corresponding Author:-Asaad Y. Ayied. 


\section{Introduction:-}

Agricultural production plays a vital role within the economic system, and livestock production represents the main elements of this production particularly sheep production (Atsan et al., 2007). As well as, sheep are the supply of basic economic financial gain and vital for several rural individuals in virtually every country (FAO, 2016). Genetic diversity is the degree of genetic variation between populations or species, through which the speedy differentiation of traits will be through the phenotype, behavior, proteins, and enzymes (Frankham, 2010). Gene COI is an associate encoded gene in the mitochondria and is found between the pairs of nucleotides 5904 and 7444 of the mitochondrial genome (Genetics Home Reference, 2018). It has been utilized in detecting processed meat product of various species due to their impact on human health (Wang et al., 2010; Nadia et al., 2012). COI gene possesses a high share of specific genetic development signals phyletic from any of the different mitochondria genes. The development of this gene isn't solely quick enough to assist distinguish species kinship, but even totally different groups developed in different countries (Waugh, 2007; Hebert et al., 2010).

The DNA sequence of this gene has been found to have sufficient variation to differentiate between numerous types of animals, birds, fish, and others (Ford et al., 2009). Amplifying mtDNA or reproduction of specific genetic regions to be studied exactly using PCR polymerase chain reaction technique (Bensasson et al., 2000). In sheep, there were five hereditary patterns of haplotypes that were distributed to a variety of breeds, as the HPG group was discovered in Asian breeds, HPG B in the European breeds and HPG C, D, E in the near east sheep breeds (Meadows et al., 2007). The genetic polymorphism of haplotypes is expected to extend because of the hybridization between completely different animal populations and breeds (Naderi et al., 2008). Othman et al., (2015) found three haplotype sorts (HPG A, B, C) in the Muflon, the Italian Sarda, Egyptian Barki, Ossimi, and Rahmani sheep breeds. Anna and Ewa, (2016) found the HPG A and B in the Polish sheep breeds.

There is great importance to genetic mitochondria in animals, including sheep, so the current study aimed to live to measure between the genetic polymorphism of the COI mitochondrial gene with milk production and therefore the growth of lambs before weaning. As well as calculating the number of haplotype and genetic variation within and between breed using molecular contrast AMOVA and neutrality test for the COI gene of Iraqi Awassi sheep.

\section{Materials and methods:-}

The study was conducted for the period from 30/11/2016 to 22/2/2017. At the laboratory of Genetic Engineering at the University of Basrah, following with the collection of data from the field up to 20/3/2018. The study included the use of 87 ewes in addition to their lambs up to the weaning at the age of 90 days. The blood samples (5ml/ewe) from the jugular vein were collected. The amount of milk production was calculated in the morning (morning milking). The amount of daily milk yield was calculated as twice the amount of morning milk production. The growth rate of the lambs was measured once every two weeks up to the age of 30 days and then monthly up to the weaning age $(1,15,30,60$ and 90 days).

The analyses were carried out on 89 Awassi ewes. Blood from each ewe was sampled intravitally into sterile vacuum tubes containing $\mathrm{K}_{2}$ EDTA (dipotassium ethylene diamine tetra acetic acid) anticoagulant. A fragment (1053 $\mathrm{Pb}$ ) of the mtDNA COI in the reference ovine mitochondrial genome Accession number AF010406.1 was amplified using two primers: Forward primer: F 5'- CAGAGTTTGAAGCTGCT-3' and Reverse primer: R 5'AGCTGACGTGAAGTAAGC-3 (Hiendleder et al, 1999). The PCR amplifications were conducted in a $50 \mu l$ volume containing $20 \mathrm{ng}$ genomic DNA, $25 \mu \mathrm{l}$ of Master Mix, $2 \mu \mathrm{l}$ each primer, $15 \mu \mathrm{l}$ free water. The amplification conditions were as follows: initial denaturation at $95 \mathrm{C}$ for $5 \mathrm{~min}$ followed by 35 cycles of denaturation at $95 \mathrm{C}$ for 1 $\mathrm{min}$, annealing at $55 \mathrm{C}$ for $1 \mathrm{~min}$, and extension at $72 \mathrm{C}$ for $1.5 \mathrm{~min}$, and then the final extension at $72 \mathrm{C}$ for $10 \mathrm{~min}$. The PCR products were electrophoresed on $2 \%$ agarose gel stained with ethidium bromide to test the amplification success. The amplified products were purified with a DNA purification kit (SSufine) according to the manufacturer's instructions to remove residual primers and dNTPs. Sequencing was performed in sync TM DNA Extraction Kit was used for DNA extraction and manufactured by the Taiwanese Geneaid company.

\section{Data Analysis}

COI sequences were aligned using the BioEdit software (Hall, 1999). Haplotype diversity (HD) and nucleotide diversity $(\pi)$ were analyzed using DnaSP v5. 10 software (Librado and Rozas, 2009). Genetic distance, molecular 
variation (AMOVA) and neutrality test were analyzed using Arlequin 3.5.1.2 software (Excoffier and Lischer, 2010). The haplotypes network was drawn using Network 5.0.0.0 software (Bandelt et al., 1999). Neighbor-joining (NJ) tree for testing camel breed sequences and the phylogenetic tree between Aussie and other sheep breeds in the world were constructed using Megaversion 7.0 software (Kumar et al, 2016).

\section{Statistical analysis:-}

The complete random design (CRD) completely Randomized design was used to analyze the data on the productive qualities studied using the SPSS (2012) Statistical program Version 22 and compared the averages using the General Linear Model within the program.

\section{Results and discussion:-}

The results of the DNA extraction showed that the concentration was from 24.3 to $65.3 \mathrm{ng} / \mu \mathrm{l}$ and that the purity of 260/280 ranged from 1.68 to 2.03 , which was detected by a Nanodrop device. The results of the electrophoresis on the agarose gel $2 \%$ showed the success of deoxyribonucleic acid amplification (Fig. 1), as the primer of COI gave a fraction of $1053 \mathrm{bp}$.

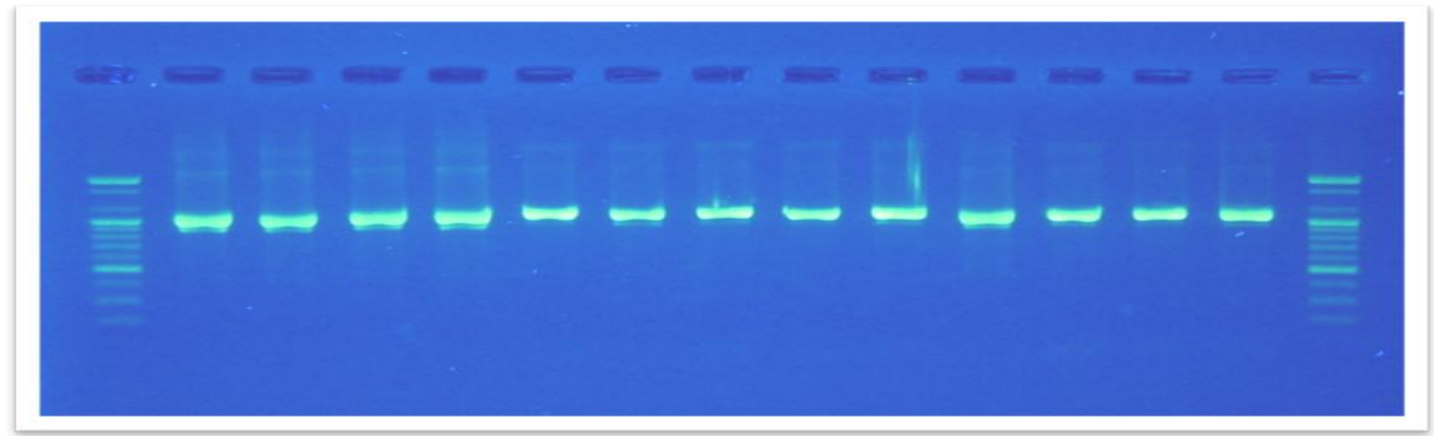

Fig 1:-The amplification product of the COI principles on the agarose gels $2 \%$.

The results of COI genetic diversity showed that there were 20 total sequences and that the number of haplotypes were 9 haplotypes resulting in 13 genetic polymorphisms (NH) (table, 1). The values of haplotype diversity (HD) and nucleotides diversity values $(\pi)$ were high in the Awassi sheep breed (0.852 and 0.00391 respectively).

Table 1:-The genetic diversity of the Iraqi Awassi sheep breed according to the genes under study

\begin{tabular}{|c|c|c|c|c|c|}
\hline Gene & $(\mathrm{N})$ & $(\mathrm{H})$ & $(\mathrm{NH})$ & $(\mathrm{HD})$ & $(\pi)$ \\
\hline COI & 20 & 9 & 13 & 0.852 & 0.00391 \\
\hline
\end{tabular}

N: Sample size; H: Haplotype; NH: Number of polymorphic; HD: Haplotype diversity $\pi$ : Nucleotide diversity.

\section{Phylogenetic tree of COI gene:}

The results of the evolutionary tree and phylogenic compared to some sheep breeds showed COI gene having four main branches. The first branch covers the Morkaraman breed, while the second branch included the Iraqi Awassi breed (Fig. 2). The third branch was branched into two secondary sections, the first section was of the Hamdani and Tibetan breed. The fourth branch being branched into two secondary branches, where the first section included the Assaf breed, while the second branch branched into two branches, with Small belong the first branch, Merino and Merinizzata descendants of the Comisana breed. The second branch was branched into two branches, the first branch consists of the Mouflon breed and Karakas and the second section consist the Karadi and Lacaune breeds. Subgroups cover Finn breed and both the Sopravissana and Gentile breeds. 


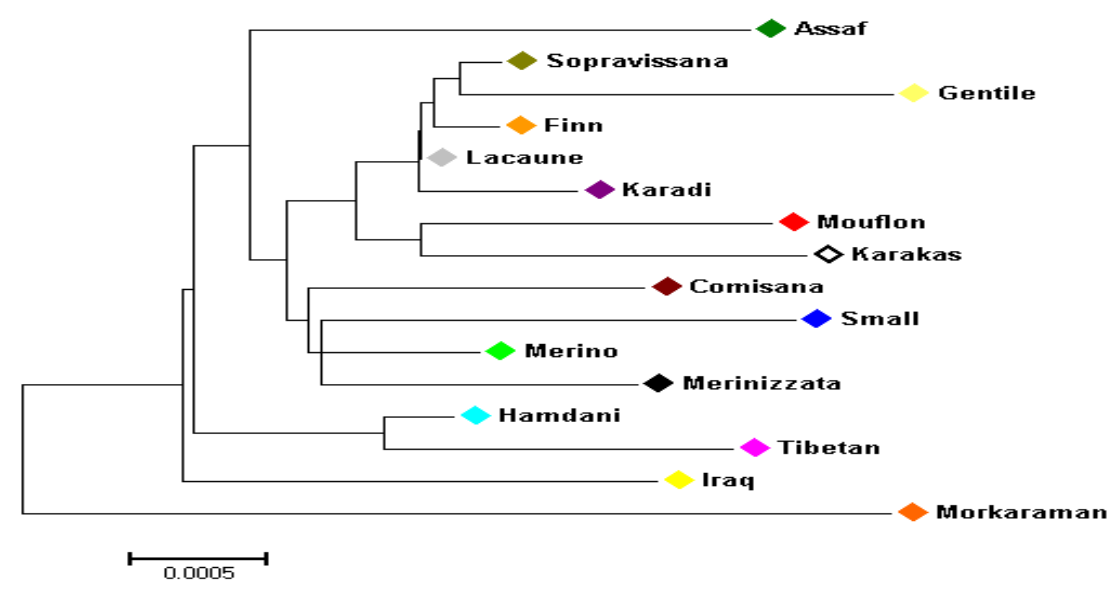

Form 2:-The Phylogenetic tree of gene COI between some states

\section{Analysis of molecular variance AMOVA}

The results of the AMOVA molecular variance analysis of the COI gene between and within sheep breeds showed that genetic variation between breeds was $13.52 \%$ and the variation within breeds was $86.48 \%$ (table 2). This finding illustrated by the fact that genetic variation within the breed is much greater than genetic variation among breeds, which may be due to the fact that the Iraqi Awassi sheep breeds have the same origin as the mother (Moradi et al., 2017).

Table 2:-Molecular contrast analysis of gene COI with strains in the world

\begin{tabular}{|c|c|c|c|c|}
\hline Source of variation & Df & Sum Squares & Variance Components & Variation \% \\
\hline Between breed & 15 & 8.741 & 0.05454 & 13.52 \\
\hline Within breed & 57 & 19.875 & 0.34868 & 86.48 \\
\hline Total & 72 & 19.875 & 0.40322 & \\
\hline
\end{tabular}

This result agreed with the findings of Rodriguez et al., (2015) and Moradi et al., (2017), who found that genetic variation within breeds is greater than genetic variation between breeds. Similar findings were also obtained by studies carried out on other animals such as goats (Silva et al., 2017), cows (Ozsensoy and Kurar, 2014) and horses (Cardinali et al., 2016).

The results of the neutrality test showed negative values for both the Tajima'D and Fu's Fs test (-0.4090,-0.51618) respectively. Which indicate an expansion in the size of the Iraqi Awassi breed (Fu, 1997), and this test is usually used to measure the probability that the population has undergone demographic events such as genetic drift or expansion of breed size. The molecular signals of sudden expansion are often interpreted as population growth or spread within the region across a wider geographical range (Bruford et al., 2003). This result was in agreement with the findings of some researchers who found negative values for both the Tajima'D and Fu's Fs test (Almathena et al., 2016; Anna and Ewa, 2016).

\section{The effect of genetic factors on milk production, birth weight and weaning weight}

The overall mean of milk production (522.99 g, table, 3) was almost similar to the findings of the Al-Samarai and Al-Anbari (2009) as they recorded $486.66 \mathrm{~g} /$ day in Iraqi Awassi. Pollott and Gootwine (2001) estimated a mean of $506 \mathrm{~g} /$ day and $505 \mathrm{~g} /$ day by Talafha and Ababneh, (2011).

While the overall mean of birth weight was $(4.52 \mathrm{~kg}$ ) (table 3). Similar results were reordered by previous investigations (Al-Azzawi, 1996; Juma and Alkass, 1996; Abdulrahman et al., 1999 Jawasra, 2000).

The overall mean weaning weight $(17.73 \mathrm{~kg})$ was in an agreement with the finding of Matika et al., (2003) in Turkish Sabi sheep (18.5 and $16.6 \mathrm{~kg}$ ) for both males and females, respectively and Emsen, (2005) in Turkish Awassi (16.80 kg). However, the present result was less than a number of researchers and different breeds of sheep in the world (Jafaroghli et al., 2013; Mirhoseinia et al., 2015; Gholizadeh and Ghafouri-kesbi, 2016; Anon, 2017). 
No significant association between this gene polymorphism and the amount of milk production and birth weight was observed. Nevertheless, the highest amount of milk $(592.67 \mathrm{~g})$ produced by ewes belong to the third genetic haplotype without reaching the significance level. The lowest amount of milk production $(486.00 \mathrm{~g})$ exhibited by the second haplotype. As for weaning weight, it was found that there was a significant effect $(\mathrm{P}<0.05)$ of COI gene polymorphism of lambs belong to the third haplotype ewes $(19.85 \mathrm{~kg})$. While the average weight of weaning in other genotypes was $17.81 \mathrm{~kg}$. Lowest weaning weight revealed by the first and second haplotypes (16.58 and 16.68 $\mathrm{kg}$ respectively).

Table 3:-Effect of gene COI on milk production, birth weight and weaning weight

\begin{tabular}{|c|c|c|c|}
\hline Traits & Mean \pm SD & Haplotype & Mean \pm SD \\
\hline \multirow[t]{4}{*}{ Daily milk production $(\mathrm{g} / \mathrm{d})$} & \multirow[t]{4}{*}{$522.99 \pm 90.25$} & H1 & $500.00 \pm 92.25$ \\
\hline & & $\mathrm{H} 2$ & $486.00 \pm 66.90$ \\
\hline & & H3 & $592.67 \pm 76.38$ \\
\hline & & Other ${ }^{*}$ & $524.74 \pm 91.79$ \\
\hline \multirow[t]{4}{*}{ Birth weight $(\mathrm{kg})$} & \multirow[t]{4}{*}{$4.52 \pm 0.70$} & $\mathrm{H} 1$ & $4.15 \pm 0.52$ \\
\hline & & $\mathrm{H} 2$ & $4.83 \pm 0.44$ \\
\hline & & H3 & $4.64 \pm 0.39$ \\
\hline & & Others ${ }^{*}$ & $4.55 \pm 0.74$ \\
\hline \multirow[t]{4}{*}{ Weaning weight $(\mathrm{kg})$} & \multirow[t]{4}{*}{$17.73 \pm 0.29$} & H1 & $16.58 \pm 0.19 \mathrm{~b}$ \\
\hline & & $\mathrm{H} 2$ & $16.68 \pm 0.21 \mathrm{~b}$ \\
\hline & & $\mathrm{H} 3$ & $19.85 \pm 0.20 \mathrm{a}$ \\
\hline & & Others ${ }^{*}$ & $17.81 \pm 0.30 \mathrm{~b}$ \\
\hline
\end{tabular}

a, b Mean with different letter differ significantly at 5\%, * Others $=$ other haplotypes

In conclusion, Iraqi Awassi sheep showed a high genetic diversity in regards to COI gene, demonstrating that this breed evolves from the center of the domestication areas. The tree of evolution has shown the presence of Iraqi Awassi with a separate branch from other sheep breeds. Genetic variation within breed was greater than genetic variation among breeds. The results of the neutrality test showed negative values in the Awassi breed, indicating an expansion of breed size. COI gene can be used as a genetic marker for weaning weight.

\section{References:-}

1. Abdulrahman FY, Khattab GK and Abdullah GI, 1999. Genetic and phenotypic features of growth qualities in Awassi sheep. The Journal of Al-Rafidain Agriculture, 31 (1): 38-48.

2. Al-Azzawi WA, 1996. Some conventional and restricted selection indexes in Awassi sheep. IPA. J. Agric. Res. 69 (1): 95-108.

3. Almathena F, Charruauc P, Mohandesanc E, Mwacharob JM, Orozco-ter WP, Pittf D, Abdussamadg AM, Uerpmannh M, Cuperei BD, Mageej P, Alnaqeebk MA, Saliml B, Raziqm A, Dessien T, Abdelhadio OM, Banabazip MH, Al-Eknahq M, Walzerd C, Fayer B, Hofreiters M, Peterst J, Hanotteb O and Burger PA, 2016. Ancient and modern DNA reveal dynamics of domestication and cross-continental dispersal of the dromedary. PNAS. 113(24): 6707-6712.

4. Al-Samarai FR and Al-Anbari N, 2009. Genetic evaluation of rams for total milk yield in Iraqi Awassi sheep, ARPN Journal of Agricultural and Biological Science. 4 (3): 54-57.

5. Anna K and Ewa S, 2016. Mitochondrial control region diversity in Polish sheep breeds. Arch. Anim. Breed. 59 (2): 227-233.

6. Anon. 2017. Annual Report, 2016-17. ICAR-Central Sheep and Wool Research Institute, Avikanagar.

7. Atsan T, Emsen E, Yaprak M, Dagdemir V and Diaz CAG, 2007. An economic assessment of differently managed sheep flocks in eastern Turkey. Ital. J. Anim. Sci. 6 (4):407-414.

8. Bandelt HJ, Forster P and Rohl A, 1999. Median-Joining Networks for inferring intraspecific phylogenies. Mol. Biol. Evol., 16(1): 37-48.

9. Bensasson D, Zhang D, Xing H and Godfrey M, 2000. Frequent Assimilation of Mitochondrial DNA by Grasshopper Nuclear Genomes, Mol. Biol. Evol. 17(3): 406-415.

10. Bruford MW, Bradley DG and Luikart G, (2003). DNA markers reveal the complexity of livestock domestication. Nature Review Genetics, 4: 900-910.

11. Cardinali I, Lancioni H, Giontella A, Cabodiferro M, Capomaccio R and Buttazzoni S, 2016. An Overview of Ten Italian Horse breeds through Mitochondrial DNA. PLoS.ONE,11(4): e0153004. 
12. Emsen E, 2005. Testicular development and body weight gain from birth to 1 year of age of Awassi and Red Karaman sheep and their reciprocal crosses. Small Ruminant Research, 59 (1): 79-82.

13. Excoffier L and Lischer HE, 2010. Arlequin suite ver. 3.5: a new series of programs to perform population genetics analyses under Linux and Windows. Molecuar Ecology Resources 10 (3): 564-567.

14. FAO, 2016. Statistics Division [Internet]. Food and Agriculture Organization of the United Nations. Available from: http://faostat.fao.org. Accessed on 15.11.2017

15. Frankham R, 2010. Inbreeding in the wild really does matter. Heredity. 104(2):124-129.

16. Ford CS, Ayres KL, Toomey N, Haider N, van Alpen Stahl J and Kelly LJ, 2009. Selection of candidate DNA barcoding regions for use on land plants. Botanical Journal of the Linnean Society, 159 (1): 1-11.

17. Fu XY, 1997. Statistical tests of neutrality of mutations against population growth, hitchhiking and background selection. Genetics, 147 (2): 915-925.

18. Genetics Home Reference, 2018. Help Me Understand Genetics Cells and DNA. Lister Hill National Center for Biomedical Communications U.S. National Library of Medicine National Institutes of Health Department of Health and Human Services Published.

19. Gholizadeh M and Ghafouri-Kesbi F, 2016. Inbreeding depression in growth traits of Baluchi sheep. Small Ruminant Research, 144: 184-190.

20. Hall TA, 1999. BioEdit: a user-friendly biological sequence alignment editor and analysis program for Windows 95/98/NT. Nucleic Acids Symposium, 41: 95-98.

21. Hebert PDN, deWaard JR and Landry JF, 2010. DNA barcodes for 1/1000 of the animal kingdom. Biology Letters, 6 (3): 359-362.

22. Hiendleder S, Phua SH and Hecht W, 1999. A diagnostic assay discriminating between two major Ovis aries mitochondrial DNA haplogroups. Anim. Genet. 30 (3): 211-213.

23. Jafaroghli M, Rashidi A, Mokhtari MS and Mirzamohammadi E, 2013. Estimation of genetic parameters for body weight traits in Baluchi sheep. Journal of Livestock Science and Technologies. 1 (2): 28-33.

24. Jawasra KIZ, 2000. Estimation of some of the genetic and non-genetic factors of some of the characteristics of growth in Jordanian Awassi sheep. MSc Thesis, College of Agriculture, University of Baghdad.

25. Juma KH and Alkass JE, 1996. Awassi sheep in Iraq. Dirasat Agric. Sci. 23 (3): 200-207.

26. Kumar S, Stecher, G and Tamura K, 2016. MEGA7: Molecular Evolutionary Genetics Analysis Version 7.0 for bigger datasets. Molecular Biology and Evolution 33 (7): 1870-1874.

27. Librado P and Rozas J, 2009. DnaSP v5: A software for comprehensive analysis of DNA polymorphism data. Bioinformatics, 25 (11): 1451-1452.

28. Matika O, Van Wyk JB, Erasmus GJ and Baker RL, 2003. Genetic parameter estimates in Sabi sheep. Livestock Production Science, 79 (1): 17-28.

29. Meadows JR, Cemal I, Karaca O, Gootwine E and Kijas JW, 2007. Five ovine mitochondrial lineages identified from sheep breeds of the Near East. Genetics, 175 (3): 1371-1379.

30. Mirhoseinia SZ, Zarea J, Hossein-Zadeha NG, Khanzadeha H, Seidavib A, Laudadioc V, Darioc C, Tufarellic V and Selvaggi M, 2015. Estimation of genetic parameters for body weight traits and pelt quality score in Iranian Karakul sheep. Small Ruminant Research, 132: 67-71.

31. Moradi MH, Phua SH, Hedayat N, Khodaei-Motlagh M and Razmkabir M, 2017. Haplotype and Genetic Diversity of mtDNA in Indigenous Iranian Sheep and an Insight into the History of Sheep Domestication. J. Agricultural Science, 19 (4): 591- 600.

32. Nadia H, Imad N and Bassam A, 2012. Identification of meat species by PCR-RFLP of the mitochondrial COI gene. Meat Science, 90 (2): 490-493.

33. Naderi S, Rezaei H, Pompanon F, Blum MGB, Negrini R and Naghash H, 2008. The goat domestication process inferred from large-scale mitochondrial DNA analysis of wild and domestic individuals. Proc. Natl. Acad. Sci. USA. 105: 17659-17664.

34. Othman E, Lorraine P, Esraa AB and Marco M, 2015. Genetic characterization of Egyptian and Italian sheep breeds using mitochondrial DNA. Journal of Genetic Engineering and Biotechnology, 13 (1): 79-86.

35. Ozsensoy Y and Kurar E, 2014. Genetic diversity of native Turkish cattle breeds: Mantel, AMOVA and bottleneck analysis. J. Adv. Vet. Anim. Res. 1(3): 86-93.

36. Pollott $\mathrm{G}$ and Gootwine $\mathrm{E}, 2001$. A genetic analysis of complete lactation milk production in Improved Awassi sheep, Livestock Production Science, 71 (1): 37-47.

37. Rodriguez MA, Gasca-Pineda J, Medellin RA and Eguiarte LE, 2015. Analysis of Genetic diversity of Bighorn Sheep (Ovis canadensis) from Mexican Population. Journal of Mammalogy, 96 (3): 473-480. 
38. Silva NMV, Pimenta FEC, Arandas JKG, Gomes FMA, Ferreira E, Del CI, Fonseca C and Ribeir MN, 2017. Polymorphism of mitochondrial DNA in the Brazilian Caninde Goat breed. Genetics and Molecule Research, 16(2): gmr 16029656.

39. SPSS 2012. Statistical Packages for Social Science, User's Guide for statistics Version 19, Copyright IBM, SPSS Inc., USA.

40. Talafha A and Ababneh M, 2011. Awassi sheep reproduction and milk production: Review. Tropical Animal Health and Production, 43 (7): 1319-1326.

41. Wang Q, Zhang X, Zhang HY, Zhang J, Chen GQ and Zhao DH, 2010. Identification of 12 animal species meat by T-RFLP on the 12 S rRNA gene. Meat Science, 85(2): 265-269.

42. Waugh J 2007. DNA barcoding in animal species: progress, potential and pitfalls. phylogenetics and systematics. Bio Essays, 29: 188-197. 